\title{
Pengaturan Uang Pengganti Sebagai Pidana Tambahan dalam Tindak Pidana Korupsi
}

\author{
Wendy, Andi Najemi \\ Fakultas Hukum, Universitas Jambi \\ Author's email correspondence: rx.wendy51@gmail.com
}

\begin{abstract}
ABSTRAK:
Artikel ini bertujuan untuk memahami dan mengevaluasi regulasi terkait pidana uang pengganti dalam tindak pidana korupsi serta untuk memahami dan mengetahui penerapan pidana uang pengganti terhadap pelaku tindak pidana korupsi. Penelitian ini merupakan penelitian hukum normatif. Dari penelitian ini ditemukan, pidana uang pengganti berstelsel pidana tambahan namun bobot pidananya dapat lebih tinggi dari pada pidana denda yang berstelsel pidana pokok, dan kurang maksimal dalam penerepan uang pengganti. Saran perlu adanya pembaharuan hukum terkait pidana uang pengganti sebagai pidana tambahan.
\end{abstract}

\section{ARTICLE HISTORY}

Submission: 10 January 2020

Accepted: 31 January 2020

Publish: 07 February 2020

\section{KEYWORDS}

Corruption; criminal; replacement money

\begin{abstract}
:
This article aims to understand and evaluate regulations relating to substitute criminal money in criminal acts of corruption as well as to understand and know the application of criminal replacement money against perpetrators of corruption. This research is a normative legal research. From this study it was found, the criminal money substitute was additionally criminal, but the criminal weight could be higher than the criminal fine which was based on principal criminal, and less than the maximum in forwarding the replacement money. Suggestions are the need for legal reform related to criminal money as an additional crime
\end{abstract}

\section{A. Pendahuluan}

Perkembangan ilmu pengetahuan, teknologi dan perkembangan sosial yang semakin maju menyebabkan modus kejahatan ikut berkembang. Era globalisasi sekarang ini selain membawa dampak positif, tetapi juga membawa dampak negatif dalam hal perkembangan modus kejahatan baru yang tengah dihadapi di berbagai negara di dunia.

Pelaku-pelaku kejahatan dewasa ini pun mengalami peningkatan dan pergeseran dari yang semula hanya pelaku kejahatan konvensional (kejahatan warungan) telah meningkat dan bergeser kepada para pelaku kejahatan yang berasal dari 
orang-orang terpandang dan berstatus sosial tinggi juga atau yang dikenal dengan "kejahatan kerah putih" (white collar crime) ${ }^{1}$.

Edwin Harland Sutherland berpendapat bahwa kejahatan kerah putih atau suatu kejahatan berdasi merupakan perbuatan yang masuk kategori yang pelakunya adalah orang-orang intelektual, berpendidikan yang ada kaitannya terhadap okupasinya ${ }^{2}$.

Modus operandi dari kejahatan kerah putih ini sering pula dilakukan dengan cara-cara modern dan tidak jarang bercampur juga dengan teori-teori dalam bidang ilmu pengetahuan. Oleh karena itu, kejahatan seperti ini apabila dilihat dari permukaannya seolah-olah perbuatan yang biasa dan legal, akan tetapi bila ditelusuri lebih lanjut, perbuatan tersebut ternyata merupakan suatu kejahatan. Pola kejahatan seperti ini termasuk kejahatan yang terselubung 3 .

Beberapa kasus tindak pidana korupsi sulit diungkapkan karena para pelakunya menggunakan peralatan yang canggih serta biasanya dilakukan oleh lebih dari satu orang dalam keadaan yang terselubung dan terorganisasi. Oleh karena itu, kejahatan ini sering disebut white collar crime atau kejahatan kerah putih4.

Kejahatan kerah putih sendiri erat kaitannya dengan korupsi, yang mana banyak dibuat oleh mereka yang mempunyai intelektual dan berpendidikan tinggi. Sebagai salah satu jenis kejahatan, korupsi memiliki karakteristik tersendiri dibandingkan dengan jenis kejahatan lain. Salah satu karakteriknya bahwa selalu berkolerasi uang serta kekuasaan. Pelakunya biasanya memiliki karakteristik tersendiri dibandingkan dengan jenis kejahatan lain. Salah satu karakteristiknya bahwa korupsi selalu berkorelasi dengan uang dan kekuasaan. Pelakunya biasanya memiliki kekuasaan, baik itu politik, ekonomi, birokrasi, hukum maupun kekuasaan yang lain.

Korupsi di Indonesia sudah dalam tingkat kejahatan korupsi politik. Kondisi Indonesia yang terserang kanker politik dan ekonomi sudah dalam stadium kritis. Kanker ganas korupsi terus menggerogoti saraf vital dalam tubuh negara Indonesia, sehingga terjadi krisis institusional. Korupsi politik dilakukan oleh orang atau institusi yang memiliki kekuasaan politik, atau oleh konglomerat yang melakukan hubungan transaksional koluktif dengan pemegang kekuasaan. Dengan demikian, praktis kejahatan luar biasa berupa kejahatan kekuasaan ini berlangsung secara sistematis ${ }^{5}$.

Istilah korupsi sesungguhnya sangat luas, mengikut perkembangan kehidupan masyarakat yang semakin kompleks serta semaking canggihnya teknologi, sehingga mempengaruhi pola pikir, tata nilai, aspirasi, dan struktur masyarakat di mana bentukbentuk kejahatan yang semula terjadi secara tradisional berkembang kepada kejahatan inkonvensional yang semakin sulit untuk diikuti oleh norma hukum yang telah ada.

Kejahatan inkonvensional menyentuh segala aspek kehidupan bangsa, mulai dari kepentingan hak asasi, ideologi negara, hingga lainnya yang menyangkut aspek perekonomian keungan negara. Korupsi bukan lagi suatu kejahatan yang biasa, melainkan kejahatan yang luar biasa (extra ordinary crime) sama dengan kejahatan

\footnotetext{
1 Edi Setiadi dan Kristian, Sistem Peradilan Pidana Terpadu dan Sistem Penegakan Hukum di Indonesia.Prenadamedia Grup, Jakarta, 2017, hlm. 4.

Ibid.

Ibid., hlm. 5.

Evi Hartati, Tindak Pidana Korupsi, Cet. 6, Edisi. 2, Sinar Grafika, Jakarta, 2016, hlm. 2.

Ibid., hlm. 3 .
} 
terorisme. ${ }^{6}$ Korupsi bukan hanya merugikan perekonomian negara, akan tetapi moral bangsa. Demikia pula, perbuatan tindak pidana korupsi merupakan pelanggaran terhadap hak-hak sosial dan hak-hak ekonomi masyarakat. Kerugian keuangan negara yang diakibatkan oleh tindak pidana korupsi berdampak pada melemahnya sektorsektor perekonomian negara, yang mengakibatkan tidak maksimalnya tercapainya tujuan negara. ${ }^{7}$ Oleh karena itu, upaya pemberantasannya tidak lagi dapat dilakukan secara biasa, tetapi dituntut cara-cara yang luar biasa. Demikian pula diperlukan usaha pemberantasannya, baik yang bersifat preventif maupun bersifat refresif8.

Ada beberapa cara yang dilakukan untuk pemberantasan tindak pidana korupsi, yaitu bersifat substantif berupa penyiapan instrumen aturan hukum korupsi. Namun secara umum upaya penanggulangan tindak pidana korupsi di Indonesia masih mengandalkan upaya penal (penal policy) yang lebih menitikberatkan pada sifat represif 9 .

Penanggulan tindak pidana korupsi melalui Upaya penal atau upaya penegakan hukum dengan penerapan hukum pidana (criminal law application) dilakukan melalui proses peradilan pidana dengan 3 (tiga) tahapan utama, yaitu (1) sebelum persidangan perkara pidana (pra-ajudikasi), (2) tahapan pada saat persidangan perkara pidana (ajudikasi),(3)tahapan sesudah persidangan (purnaajudikasi). Salah satu keluaran (output) dari tahapan pra-ajudikasi dan ajudikasi adalah dengan dikenakan sanksi pidana terhadap pelaku (terdakwa) tindak pidana korupsi, dan diantara sanksi pidana tersebut adalah pidana pembayaran uang pengganti (PUP) yang diesekusi pada tahapan purna-ajudikasi ${ }^{10}$.

Usaha-usaha terus dilaksanakan untuk mengembalikan kerugian negara yang hilang karena adanya perilaku korupsi para koruptor. Di dalam rumusan pasal yang diatur di dalam Undang-Undang Pemberantasan Tindak Pidana Korupsi memuat beberapa hal mengenai kerugian keuangan negara.

Akibat terjadinya perbuatan penyelewengan, maka negara mengalami kerugian atau kehilangan sejumlah kekayaan akibat dari perbuatan memperkaya diri si pembuat. Padahal dengan mencantumkannya kata "dapat", mengandung arti negara belum menderita kerugian keuangan secara nyata. Kata "dapat" dalam unsur dapat merugikan keuangan negara harus diartikan sebagai potensial atau potensinya saja sudah cukup untuk terjadinya tindak pidana korupsi Pasal 2 ayat (1) Undang-Undang Pemberantasan Tindak Pidana Korupsi. keadaan ini membuktikan bahwa terdapatnya potensi merugikan keuangan negara dan kerugian keuangan nyata tersebut belum terjadi, dianggap bukan merupakan percobaan tindak pidana, melainkan tindak pidana selesai ${ }^{11}$.

Penjatuhan pidana pada para pelaku yang melakukan tindak pidana korupsi dijatuhi pidana yang diantaranya pidana pokok dan pidana tambahan, Dalam pidana

6 Lihat Mohamad Rapik et.al., "Peran Forum Koordinasi Pencegahan Terorisme dalam Menjalankan Program Deradikalisasi," Journal of Political Issues, 1 (2), 2020., hlm. 104.

7 Lihat Ridwan Arifin et.al., "A Comparative Analysis of Indonesia's KPK and Hong Kong ICAC in Eradicating Corruption," Jambe Law Journal, Vol. 2.No.2, 2019, hlm. 167.

8 Chaerudin, Syaiful Ahmad Dinar dan Syarif Fadillah, Op. Cit, hlm. 17

9 Basir Rohrohmana, Pidana Pembayaran Uang Pengganti Sebagai Pidana Tambahan Dalam Tindak Pidana Korupsi, Jurnal Hukum Prioris Vol. 6 No. 1. Tahun 2017. hlm. 45.

10 Ibid., hlm. 45-46.

11 Adami Chazawi, Hukum Pidana Korupsi Di Indonesia, edisi revisi, Rajagrafindo Persaja, Jakarta, 2016, hlm. 33. 
tambahan dikenal dengan adanya pidana uang pengganti. ${ }^{12}$ Berdasarkan Pasal 18 ayat (2) Tersebut, merumuskan bahwa pembayaran uang pengganti sudah harus dibayar paling lama 1 (satu) bulan. pembayaran terhadap uang pengganti dan konsekuensi yang berlaku terhadap limitasi waktu pembayaran tersebut diatur dalam Pasal 9 ayat (1), ayat (2), ayat (3), dan ayat (4) Peraturan Mahkamah Agung Republik Indonesia Nomor 5 Tahun $2014 .{ }^{13}$

Pembayaran uang pengganti di dalam lingkup normatif dan praktis bisa menimbulkan persoalan hukum. Lingkup normatif pidana pembayaran uang pengganti dilihat dari stelsel pidananya merupakan pidana tambahan, namun berat ringan pembayaran uang pengganti (strafmaatnya) dapat saja melebihi ancaman pidana pokok denda, sebab hal itu secara kasuistis tergantung pada jumlah hasil korupsi pada tiap tindak pidana korupsi ${ }^{14}$.

Pidana Pembayaran Uang Pengganti dapat diganti dengan pidana penjara yang lamanya disebutkan dalam putusan hakim dengan ketentuan tidak melebihi ancaman pidana pokok, tidak ada batas minimal dari pidana pokok yang dikonversikan sebagai subsider dari pembayaran uang pengganti, dan dengan adanya subsider dari pembayaran uang pengganti banyak dari pelaku korupsi yang lebih memilih pengganti (subsidernya) dari pembayaran uang pengganti dari pada untuk membayaran uang pengantinya, dengan alasan tidak ada uang untuk membayar uang pengganti tersebut.

Pengaturan terhadap pembayaran uang pengganti sendiri dirasa masih kurang tegas dalam hal pengaturannaya, masih banyak pengaturannya sendiri yang masih belum jelas seperti pengaturan mengenai konversi dari pembayaran uang pengganti untuk disubsiderkan menjadi pidana penjara. Mengenai batasannya, hanya batasan maksimal ditentukan di dalam undang-undang yang lamanya tidak melewati maksimal dari ancaman pidana pokok penjara.

Pemberantasan tindak pidana korupsi di Indonesia merupakan suatu upaya pengembalian kerugian negara yang dilakukan oleh negara melalui aparat penegak hukum. Ada beberapa persoalan dalam hal pembayaran uang pengganti yang dihadapi para aparat penegak hukum, baik karena peraturan perundang-undangnya sendiri belum secara tegas mengatur maupun sulitnya menjangkau para pelaku untuk mau membayar uang pengganti.

Persoalan-persoalan berkenaan dengan penjatuhannya dalam proses peradilan dan terkait hukum pelaksanaan pidana, khususnya pelaksanaan pidana tambahan berupa "pembayaran uang pengganti". Persoalan ini menjadi penting mengingat paling tidak dua alasan:

Pertama, kedudukan pidana pembayaran uang pengganti sebagai "lembaga baru" dalam sistem hukum pidana Indonesia, menyebabkan masih sangat sedikit pengaturannya. Bahkan dapat dikatakan mengalami kekosongan pengaturan (regelsvacuum), sehingga memerlukan "manuver interpretasi" ketentuan yang ada. Kedua, fokus pengaturan dalam hukum korupsi selama ini tertujuan pada masalah hukum materiel (hukum pidana substantif) dan hukum formilnya

12 Lihat Pasal 18 ayat (1),(2),(3) UU No.31 Tahun 1999 sebagaimana telah diubah dengan Undang-Undang Nomor 20 Tahun 2001 Tentang Pemberantasan Tindak Pidana Korupsi

13 Lihat pasal Pasal 9 ayat (1), ayat (2), ayat (3) dan ayat (4). Peraturan Mahkamah Agung Republik Indonesia Nomor 5 Tahun 2014)

14 Basir Rohrohmana, Op. Cit, hlm. 44. 
(hukum acara pidana). Sementara itu, masalah hukum pelaksanaan pidananya kerap kali terlupakan ${ }^{15}$.

Permasalahan mengenai pemberantasan tindak pidana korupsi memang menjadi masalah serius yang tengah dihadapi Indonesia sekarang ini, baik dari sulitnya menjangkau para pelaku korupsi untuk mengembalikan uang negara maupun dari hukumnya sendiri. Tidak sendikit dari terpidana dijatuhkan pidana pembayaran uang pengganti, yang lebih memilih konversi-subsider dari uang pengganti dengan alasan tidak ada harta kekayaan lagi untuk membayar uang pengganti tersebut. Hal ini terjadi karena masih kurang tegasnya peraturan yang telah ada sehingga menimbulkan celahcelah hukum yang dimanfaatkan terpidana, untuk tidak membayar uang pengganti.

Hal ini tentu harus menjadi suatu pertimbangan yang sangat penting mengingat tujuan dalam pembentukan Undang-Undang Pemberantasan Tindak Pidana Korupsi selain memberikan efek jera kepada pelaku tindak pidana korupsi juga bertujuan untuk mengupayakan agar kerugian keuangan negara dapat dikembalikan sehingga lebih bermanfaat dalam membantu pembangunan bangsa Indonesia menjadi lebih baik di masa yang akan datang ${ }^{16}$.

Pembayaran uang pengganti sebenarnya berkaitan dengan tujuan pemerantasan tindak pidana korupsi meliputi: (1) follow the suspect atau (2) follow the money. ${ }^{17}$ Pendekatan tujuan dari follow the suspect adalah berfokus pada penjatuan sanksi dan memberikan efek jera kepada pelaku tindak pidana korupsi. Sedangkan pendekatan tujuan follow the money merupakan upaya untuk mengembalikan keuangan negara ${ }^{18}$.

\section{B. METODE PENELITIAN}

Jenis penelitian yang digunakan dalam penelitian ini adalah penelitian hukum normatif, dimana penelitian ini berangkat adanya isu hukum. Penelitian hukum dilakukan untuk menghasilkan argumentasi,teori, atau konsep baru sebagai preskripsi dalam menghadapi masalah yang dihadapiPenelitian hukum normatif merupakan jenis penelitian hukum yang diperoleh dari studi kepustakaan, dengan menganalisis suatu permasalahan hukum melalui peraturan perundang-undangan, literatur-literatur dan bahan-bahan referensi lainnya.

\section{PEMBAHASAN}

\section{Proses Pidana Uang Pengganti Terhadap Tindak Pidana Korupsi}

Pidana Tambahan adalah pidana yang ditambahkan terhadap pidana pokok. Pidana tambahan menurut sifatnya adalah fakultatif. ${ }^{19}$ Pidana tambahan hanya dapat dijatuhkan di samping pidana pokok. Oleh sebab itu pidana tambahan boleh saja tidak dijatuhkan, tetapi ada juga pidana tambahan bersifat imperatif, dalam hal ini seperti yang diatur dalam Pasal 250 bis, Pasal 261 dan Pasal 275 KUHP. Dengan demikian

15 http://huda-drchairulhudashmh.blogspot.com/2015/06/menyoal-pidana-tambahanpembayaran-uang.html. Diakses pada tanggal 16 Oktober 2018. Pukul 09.00 WIB.

16 Nys. Arfa, Analisis Yuridis Penjatuhan Pidana Tambahan Uang Pengganti dalam UndangUndang Nomor 31 Tahun 1999 Jo undang-Undang Nomor 20 Tahun 2001 Tentang Pemberantasan Tindak Pidana Korupsi, Jurnal Ilmu Hukum, Volume 8, Nomor 1, Maret 2017, hlm. 37.

17 Basir Rohrohmana, Op. Cit, hlm. 51

18 Ibid., hlm. 52.

19 Ibid., hlm. 53 
pidana tambahan secara umum dapat dikatakan adalah pidana yang tidak bisa dijatuhkan sendiri tanpa adanya pidana pokok. Di samping itu pidana tambahan memang sifatnya dasarnya tidak imperative atau suatu keharusan untuk dijatuhkan, bisa juga hanya dijatuhkan pidana pokok tanpa disertai pidana tambahan.

Rumusan pasal 10 KUHP dikenal 3 (tiga) jenis pidana tambahan, yaitu: (1) pencabutan hak-hak tertentu (diatur lebih lanjut dalam pasal 35, Pasal 36, Pasal 37, dan Pasal 38 KUHP), (2) perampasan barang-barang tertentu (diatur lebih lanjut dalam Pasal 39 , Pasal 40, Pasal 41, dan Pasal 42 KUHP), (3) pengumuman putusan hakim (diatur lebih lanjut dalam Pasal 43 KUHP)

Ketentuan Pasal 18 ayat (1), ayat (2), dan ayat (3) Undang-Undang Nomor 31 Tahun 1999 jo Undang-Undang Nomor 20 Tahun 2001 Tentang Pemberantasan Tindak Pidana Korupsi di atas mengandung beberapa hal mendasar berkaitan dengan kedudukan pidana pembayaran uang pengganti sebagai pidana tambahan dalam tindak pidana korupsi, secara umum bahwa Undang-Undang tindak pidana korupsi memberlakukan stelsel pidana tambahan yang terdapat dalam Pasal 10 KUHP, yang berarti bahwa Undang-Undang Tindak Pidana Korupsi menambah jenis sanksi pidana tambahan.

Secara penafsiran grammatikal bahwa makna kata "pembayaran" dalam Pasal 18 ayat (1) huruf b mengandung arti proses, cara, perbuatan membayar. Maka secara keseluruhan makna pembayaran uang pengganti yang jumlahnya sebanyak-banyaknya sama dengan harta benda yang diperoleh dari tindak pidana korupsi ialah merupakan proses membayar terhadap kepada negara terhadap besarnya kerugian negara yang disebabkan oleh suatu tindak pidana korupsi.

Besaran uang pengganti yang harus dibayar oleh pelaku yaitu sebanyakbanyaknya sama dengan harta benda yang diperoleh dari tindak pidana korupsi. ketentuan Pasal 18 ayat (1) huruf b Undang-Undang Pemberantasan Tindak Pidana Korupsi ini bersifat fleksibel. Artinya bahwa jumlah pidana pembayaran uang pengganti mengikuti besar kecilnya jumlah harta benda yang diperoleh dari tindak pidana korupsi (sebesar hasil tindak pidana korupsi). Sifat fleksibelitas pidana pembayaran uang pengganti yang demikian menyebakan dapat saja jumlah atau besaran pidana pembayaran uang pengganti yang dikenakan hakim terhadap terpidana mengandung kemungkinan jauh lebih besar dari pada pidana denda dalam tindak pidana korupsi yang merupakan pidana pokok, bahwa ada pula dikenakan secara sekaligus antara pidana denda sebagai pidana pokok dan pidana pembayaran uang pengganti sebagai pidana tambahan dalam suatu perkara korupsi yang harus ditunaikan oleh terpidana tindak pidana korupsi.

Pembayaran uang pegganti ditentukan waktu pembayarannya, yakni paling lama dalam waktu 1 (satu) bulan sesudah putusan pengadilan yang telah memperoleh kekuatan hukum tetap. Selain itu ditentukan pula konsekuensi dari tidak dipenuhinya pembayaran dalam waktu 1 (satu) bulan, yakni harta benda terpidana dapat disita oleh jaksa dan dilelang untuk menutupi uang pengganti tersebut. Konsekuensi berikutnya dalam hal harta benda terpidana tidak mencukupi untuk membayar uang pengganti, maka terpidana dipidana dengan pidana penjara yang lamanya tidak melebihi ancaman maksimum dari pidana pokoknya sesuai ketentuan dalam undang-undang tindak pidana korupsi dan lamanya pidana tersebut ditentukan dalam putusan pengadilan. 
Dalam hal penentukan batas waktu dan konsekuensi pembayaran uang pengganti diatur dalam Pasal 9 ayat (1), ayat (2), ayat (3), dan ayat (4) Perma Nomor 5 Tahun 2014 Tentang Pidana Tambahan Uang Pengganti Dalam Tindak Pidana Korupsi.

Pasal 9

(1) Apabila dalam jangka waktu 1 (satu) bulan setelah putusan berkekuatan hukum tetap, terpidana tidak melunasi pembayaran uang pengganti, jakwa wajib melakukan penyitaan terhadap harta benda yang dimiliki terpidana.

(2) Jika setelah dilakukan penyitaan sebagaimana dimaksud ayat (1) terpidana tetap tidak melunasi pembayaran uang pengganti, Jaksa wajib melelang harta benda tersebut dengan berpedoman pada Pasal 273 ayat (3) KUHAP.

(3) Pelaksanaan lelang dilakukan selambat-lambatnya 3 bulan setelah dilakukan penyitaan.

(4) Sepanjang terpidana belum selesai menjalani pidana penjara pokok, Jaksa masih dapat melakukan penyitaan dan pelelangan terhadap harta milik terpidana yang ditemukan.

Ketentuan dalam Perma tersebut di atas merupakan penegasan dan pengaturan lebih lanjut dari ketentuan Pasal 18 Undang-Undang Pemberantasan Tindak Pidana Korupsi, khusus berkenaan dengan eksekusi pembayaran uang pengganti dalam ketentuan Perma tersebut bahwa jaksa merupaka eksekutor pembayaran uang pengganti dan sebagai eksekutor penyitaan dan pelelangan terhadap harta benda milik terpidana, manakala terpidana dalam waktu 1 (satu) terpidana tetap tidak melunasi pembayaran uang pengganti dengan tetap berpedoman pada Pasal 273 ayat (3) KUHAP.

Berdasarkan pasal tersebut, batas waktu pelelangan yakni selambat-lambatnya 3 (tiga) bulan setelah melakukan penyitaan yang dilakukan oleh jaksa. Mengenai pelelangan belum mencukupi untuk membayar uang pengganti, sepanjang terpidana belum selesai menjalani pidana penjara pokok, jaksa masih dapat melakukan penyitaan dan pelelangan terhadap harta milik terpidana yang ditemukan. Jadi selama masa waktu pidana pokok penjara belum selesai, jaksa masih dapat melakukan penyitaan terhadap harta benda yang dimiliki terpidana untuk dapat melunasi pembayaran uang pengganti. Dalam hal terpidana tidak sanggup membayar uang pengganti meskipun harta bendanya telah disita dan dilelang, maka pembayaran uang pengganti berlaku pidana subsider, yang mana subsider uang pengganti disubsiderkan pidana penjara yang lamanya tidak melebihi ancaman maksimum dari pidana pokoknya.

Pidana denda yang merupakan pidana pokok, apabila terpidana tidak sanggup membayar pidana denda tersebut, pidana denda tersebut dapat disubsider dengan pidana kurungan pengganti yang ditentukan dalam putusan pengadilan.

Lamanya kurungan pengganti diatur dalam Pasal 41 ayat (2) KUHP menyebutkan: "pidana kurungan pengganti paling sedikit satu hari dan paling lama enam bulan". Dari ketentuan kurungan pengganti dari pidana denda tersebut, jika dikaitkan dengan pidana pembayaran uang pengganti dalam tindak pidana korupsi, lamanya subsider pidana pokok denda lebih ringan yang hanya berupa kurungan, sedangkan pada pidana pembayaran uang pengganti yang merupakan pidana tambahan subsidernya merupakan pidana penjara yang tidak melebihi ancaman pidana pokok penjara.

Lamanya pidana pokok sebagai konversi dari pidana pembayaran uang pengganti dapat ditafsirkan bahwa pidana pembayaran uang pengganti yang 
merupakan pidana tambahan dapat dikonversi atau dijadikan sebagai pidana pokok walaupun sifatnya subsider dari uang pengganti. Meski subsider, konversi demikian bukan lagi dikonversikan dengan pidana tambahan melainkan pidana pokok berupa penjara. Tidak ada batas minimal dari pidana pokok yang dikonversikan sebagai subsider uang pengganti, melainkan hanya ditentukan batasan maksimal dari konversi uang pengganti, tidak melebihi ancaman pokok. Jadi pidana pembayaran uang pengganti merupakan pidana tambahan yang dapat dikonversikan-subsider pidana penjara, walaupun sifat darinya sebagai pidana tambahan namun bobot penerapannya sama seperti pidana pokok.

Penjatuhan pidana uang pengganti berpegang pada Pasal 18 ayat (1) huruf a dan b Undang-Undang Pemberantasan Tindak Pidana Korupsi, sebelum sampai kepada penjatuhan pidana uang pengganti yang mana dilakukan setelah adanya putusan yang telah memiliki kekuatan hukum yang tetap (inkracht), pada proses penyelidikan dan proses penyidikan memiliki peran penting dalam proses rencana penelusuran aset hasil tindak pidana korupsi, penelusuran aset sangat penting, yang mana rencana penelusuran aset dipergunakan dalam hal mengetahui keberadaan aset yang disembunyikan oleh para pelaku tindak pidana korupsi. Keberadaan aset tindak pidana korupsi diperuntukan dalam hal proses penyitaan yang dilakukan oleh penyidik sebagai serangkaian penyidikan yang digunakan dalam hal proses pembuktian di persidangan (ajudikasi) maupun dalam hal eksekusi putusan hakim yang telah inkrach yang menjatuhkan pidana uang pengganti sebagai pidana tambahan, yang mana dalam pidana uang pengganti memiliki konsekuensi apabila dalam waktu 1 (satu) bulan terpidana tidak mampu membayar uang pengganti maka harta bendanya disita oleh jaksa dan dilelang untuk menutupi uang pengganti tersebut (Pasal 18 ayat (2)).

Kegiatan penelusuran aset dapat dilakukan dengan memanfaatkan data awal yang sudah diperoleh pada tahap penyelidikan, maupun pada saat penyidikan untuk selanjutnya ditelusuri misalnya dengan memanfaatkan data publik melalui internet, maupun kerjasama dengan lembaga keuangan baik bank maupun non-bank, maupun lembaga-lembaga lain yang memiliki kemungkinan memiliki data mengenai penelusuran aset perkara tindak pidana korupsi yang tengah dihadapi.

Komisi Pemerantasan Korupsi (KPK) memiliki unit asset tracing yang memang dikhususkan untuk membantu penanganan perkara korupsi mulai dari tahap penyelidikan. Data dan informasi terkait dengan aset yang telah diperoleh pada tahap penyelidikan akan ditindaklanjuti dengan penyitaan, pemblokiran dan tindakan lain yang diperlukan pada tahap penyidikan.

Aset yang telah didapat berupa barang bergerak yang berwujud atau yang tidak berwujud atau barang tidak bergerak yang digunakan untuk atau yang diperoleh dari tindak pidana korupsi, aset tersebut kemudian disita sesuai dengan amanat Pasal 38 KUHAP, aset tersebut digunakan dalam proses pembuktian di persidangan, dan juga aset tersebut sekaligus sebagai jaminan dalam hal penjatuhan pidana uang pengganti. Aset tersebut sebagai jaminan dalam hal penjatuhan pidana uang pengganti, yang apabila tidak dibayarkan oleh terpidana dalam jangka waktu 1 (satu) bulan, dari hasil perampasan tersebut dijadikan sebagai barang sitaan jaksa (eksekutor) yang kemudian dilelang untuk menutupi uang pengganti tersebut.

Dari penjelasan diatas, pembayaran uang pengganti merupakan pidana tambahan dalam tindak pidana korupsi, yang tenggang waktu pembayaran uang pengganti paling lama 1 (satu) bulan setelah putusan hakim yang berkekuatan hukum 
tetap (inkracht), dan apabila selama 1 (satu) bulan terpidana tidak mampu membayar uang pengganti, harta benda terpidana disita dan dilelang oleh jaksa untuk menutupi uang pengganti, apabila harta benda terpidana tidak pencukupi untuk melunasi uang pengganti, maka pembayaran uang pengganti yang tidak dibayarkan dapat disubsiderkan pidana pokok penjara yang lamanya tidak melebihi ancaman pokok penjara. Proses penelusuran aset tindak pidana korupsi dilakukan pada tahap penyelidikan dan penyidikan yang kemudian disita yang digunakan dalam proses pembuktian di persidangan, dan sebagai jaminan dalam penjatuhan pidana uang pengganti, yang apabila tidak dibayarkan dalam waktu 1 (satu) bulan aset tersebut dapat dijadikan barang sitaan jaksa dan dilelang untuk menutupi uang pengganti tersebut. Untuk konversi dari subsider pembayaran uang pengganti perlu adanya pengaturan mengenai jumlah besaran uang pengganti yang dikonversikan menjadi pidana pokok penjara, besaran tersebut berupa penggolongan dari taksiran uang pengganti yang tidak dibayarkan oleh terpidana menjadi subsider pidana penjara dengan batasan maksimun tidak melebihi ancaman pidana pokok.

\section{Penerapan Pidana Uang Pengganti Terhadap Pelaku Tindak Pidana Korupsi}

Dasar hukum bagi hakim dalam memberikan vonis pidana tambahan berupa uang pengganti pada tindak pidana korupsi diatur berdasarkan ketentuan Pasal 18 Undang-Undang Pemberantasan Tindak Pidana Korupsi, upaya pemberantasan tindak pidana korupsi secara hukum dengan memberlakukan secara konsisten UndangUndang Tentang Pemberantasan Tindak Pidana Korupsi dan berbagai ketentuan terkait secara refresif, yaitu dengan menerapkan upaya pemidanaan terhadap pelaku tindak pidana korupsi dengan menghukum terpidana dengan pidana penjara dan pidana denda, serta menjatuhkan sanksi pembayaran uang pengganti sebagai pidana tambahan dalam perkara korupsi untuk mengembalikan kerugian terhadap keuangan negara.

Proses pengembalian kerugian keuangan negara melalui penjatuhan sanksi pembayaran uang pengganti dalam tindak pidana korupsi tersebut, terpidana dituntut pidana tambahan uang pengganti yang jumlahnya sebanyak-banyaknya sama dengan harta benda yang diperoleh dari hasil tindak pidana korupsi bukan semata-mata sejumlah kerugian keuangan negara yang diakibatkan.

Sejalan dengan karakteristik tindak pidana korupsi yang sebagian besar deliknya berhubungan dengan uang, baik terkait dengan upaya penyelamatan atau pengembalian keuangan negara, maupun penyelusuran hasil kejahatan dalam berbagai bentuknya, maka kegiatan penelusuran aset harus direncanakan secara matang.

Kegiatan penelusuran aset dapat dilakukan dengan memanfaatkan data awal yang sudah diperoleh tahap penyelidikan, maupun pada saat penyidikan untuk selanjutnya ditelusuri. Penelusuran aset terkadang terbantu dengan memanfaatkan data publik yang ada di internet melalui website formal maupun sumber-sumber informasi lain untuk kemudian ditindaklanjuti. Penelusuran aset juga dapat dilakukan dengan koordinasi dengan lembaga keuangan baik bank maupun non-bank, PPATK, BPN dan lain-lain.

Penelusuran aset juga dapat dilakukan dengan melakukan pemeriksaan terhadap para pihak yang diduga mengetahui adanya aset yang terkait dengan tindak pidana yang disidik. Penelusuran tentang aset baik berupa barang bergerak maupun barang tidak bergerak sedapat mungkin disertai dengan surat-surat. Hal ini penting karena 
untuk memudahkan penyelesaian (eksekusi) dalam hal perkara sudah mendapatkan putusan hakim.

Terkait dengan telah ditemukan dugaan tindak pidana korupsi dan aset yang diperoleh dari hasil tindak pidana korupsi penyidik berdasarkan Pasal 38 KUHAP. (lihat Pasal 38 KUHAP) Penyitaan yang dilakukan oleh penyidik dalam perkara korupsi, hendaknya memperhatikan aspek penyelamatan aset. Penyitaan dalam perkara korupsi dikaitan dengan aset yang digunakan atau diperoleh dari tindak pidana korupsi dengan memperhatikan Pasal 18 ayat (1) huruf a. Demikian pula dengan upaya pembayaran uang pengganti dengan memperhatikan pada ketentuan Pasal 18 ayat (1) huruf b, ayat (2) dan ayat (3).

Tindakan penyitaan harus disertai dengan surat perintah penyitaan. Dalam keadaan tertentu tindakan penyitaan dapat dilakukan sebelum mendapatkan ijin dari pengadilan, baru setelah tindakan penyitaan dilakukan kemudian meminta penetapan penyitaan dari pengadilan. Pasal 18 ayat (1) huruf a menyatakan bahwa perampasan barang bergerak yang berwujud atau yang tidak berwujud atau barang tidak bergerak yang digunakan untuk atau yang diperoleh dari tindak pidana korupsi dilakukan, begitu pula dari barang yang menggantikan barang-barang tersebut. Berdasarkan penafsiran secara autentik Pasal 18 ayat (1) huruf a di dalam penjelasan pasal tersebut menyatakan "cukup jelas". Akan tetapi mengenai penerapannya masih kurang maksimal, mengenai penyitaan ini KPK sangat berperan aktif dibandingkan dengan peran jaksa dalam hal perampasan barang hasil tindak pidana korupsi.

Penyelusuran aset dari hasil tindak pidana korupsi yang telah diketahui oleh penyidik sejak awal, disita oleh penyidik sebagai serangkaian tindakan penyidik untuk mengambil alih dan/atau menyimpan di bawah penguasaannya untuk kepentingan pembuktian dalam penyidikan, penuntutan dan peradilan. Dengan diketahuinya aset tersebut sehingga menjadi pedoman bagi jaksa nantinya, dalam hal hakim dalam menjatuhkan putusan yang berupa pidana penjara dan denda serta pidana tambahan berupa pembayaran uang pengganti, apabila dalam eksekusi pembayaran uang pengganti tersebut, terpidana tidak mampu membayar uang pengganti dengan alasan tidak ada harta kekayaan untuk membayar uang pengganti tersebut, dengan adanya penyitaan yang dilakukan oleh penyidik pada tahap penyidikan, jaksa dapat melakukan lelang terhadap barang sitaan yang dilakukan oleh penyidik sehingga tujuan dalam hal pemulihan keuangan negara dapat terwujud, sehingga meminimalisir adanya penyembunyian aset oleh terpidana.

Pada tahun 2018 Komisi Pemberatasan Korupsi (KPK) melakukan 157 kegiatan penyelidikan, 178 penyidikan, dan 128 penuntutan, baik kasus baru maupun sisa penanganan pada tahun sebelumnya. Selain itu juga melakukan eksekusi terhadap 102 putusan pengadilan yang telah berkekuatan hukum tetap.

Lebih dari 500 miliar rupiah telah dimasukkan ke kas negara dalam bentuk PNBP dari penangan perkara. Termasuk di dalamnya dari pendapat hasil lelang barang sitaan dan rampasan dari perkara tindak pidana korupsi maupun tindak pidana pencucian uang sebesar Rp. 44.6 Miliar.

KPK melalui unit Pelacakan Aset, Pengelolaan Barang Bukti dan Sitaan (Labuksi) berusaha untuk mengoptimalkan pemulihan aset (asset recovery) dari perkara korupsi dan TPPU. Selain melakukan lelang bersama DJKN, eksekusi barang rampasan juga dilakukan dengan pemanfaatan status penggunaan (PSP) dan hibah. Pola eksekusi ini digunakan karena mendesaknya kebutuhan pemerintah pusat atau pemerintah daerah terhadap barang rampasan negara baik barang 
rampasan negara yang bergerak maupun tidak bergerak untuk kegiatan pemerintahan ${ }^{20}$.

Berdasarkan penjelasan di atas, Pasal 18 ayat (1) huruf a dan b merupakan satu kesatuan dalam proses peradilan pidana, baik pada awal proses penyelidikan dan penyidikan apabila ditemukan barang dari hasil tindak pidana korupsi berdasarkan amanat pasal tersebut perlu adanya perampasan barang yang akan digunakan dalam proses pembuktian pada proses persidangan, serta pada akhirnya pada saat eksekusi putusan hakim yang telah inkracht barang rampasan tersebut menjadi suatu jaminan dalam hal penjatuhan pidana uang pengganti yang apabila terpidana tidak mampu membayar uang pengganti tersebut, hasil rampasan tersebut dapat dilelang untuk menutupi uang pengganti tersebut

Dalam hal penentuan jumlah pembayaran uang pengganti dalam tindak pidana korupsi, adalah sebanyak-banyaknya sama dengan harta benda yang diperoleh dari tindak pidana korupsi dan bukan semata-mata sejumlah kerugian keuangan negara yang diakibatkan. Kemudian harta benda hasil korupsi yang sebelumnya disita terlebih dahulu oleh penyidik akan diperhitungkan dalam menentukan jumlah uang pengganti yang harus dibayarkan terpidana.

Pembayaran uang pengganti dalam tindak pidana korupsi dilaksanakan setelah putusan pengadilan yang telah mempunyai kekuatan hukum tetap (inkracht), terpidana diberi tenggang waktu 1 (satu) bulan untuk melunasi pidana tambahan berupa uang pengganti, di mana setelah dilakukan pelunasan pembayaran, jaksa akan menyetor pembayaran uang pengganti yang ditandatangani oleh jaksa dan terpidana kepada Pengadilan Negeri yang mengadili perkara.

Laporan Tahunan Kejaksaan Republik Indonesia Tahun 2016 (terlampir), dimana penyelesaian pembayaran uang pengganti tidak maksimal yang mana pada priode 2016 untuk pembayaran uang pengganti hanya Rp. 607.553.065.194,88,-, namun untuk sisa per 31 Desember 2016 Rp. 5.839.670.808.803, 49,-, sehingga berpengaruh terhadap pemulihan kerugian negara.

Berdasarkan penjelasan diatas penerapan pembayaran uang pengganti yang merupakan pidana tambahan dalam tindak pidana korupsi, jaksa merupakan eksekotur putusan hakim memiliki waktu 1 (satu) bulan dalam mengeksekusi pembayaran uang pengganti yang dibebankan kepada terpidana, apabila setelah 1 (satu) bulan terpidana tidak sanggup membayar uang pengganti tersebut sesuai putusan pengadilan yang berkekuatan hukum tetap, maka jaksa wajib menyita dan melelang harta terpidana untuk menutupi uang pengganti yang dibebankan kepada terpidana, namun apabila dalam penyitaan tersebut masih tidak mencukupi untuk membayar uang pengganti, maka pembayaran uang pengganti tersebut disubsiderkan pidana penjara yang lamanya tidak melebihi ancaman pokok pidana penjara.

Untuk memaksimalkan pemulihan keuangan negara sebagai tujuan dari dibentuknya Undang-Undang Pemberantasan Tindak Pidana Korupsi, perlu adanya pembaharuan dibidang Hukum yang berkaitan dengan tindak pidana korupsi khususnya dalam penerapan uang pengganti, yaitu perlu adanya interval untuk

20 https://www.kpk.go.id/id/berita/siaran-pers/717-capaian-dan-kinerja-kpk-di-tahun-2018. Diakses Pada tanggal 05 Mei 2019, pukul 15.00 WIB. 
subsider uang pengganti yang tidak mampu dibayarkan agar tercapai nilai kepastian hukum.21

Pidana pembayaran uang pengganti sebagai bentuk pidana tambahan yang diputus oleh hakim dalam putusannya, untuk proses pembayaran uang pengganti dapat dengan mencicilnya dengan ketentuan batas waktu pencicilan yang ditentukan. Serta untuk penjatuhan uang pengganti, apabila siterpidana sanggup membayar uang pengganti yang dibebankan kepadanya, maka untuk pidana pokoknya tidak perlu lagi adanya dengan pidana pokok. Namun perlu adanya interval untuk subsider uang pengganti yang tidak mampu dibayarkan agar menjamin suatu kepastian hukum.

\section{Simpulan}

Pidana uang pengganti berstelsel pidana tambahan namun bobot pidananya dapat lebih tinggi dari pada pidana denda yang berstelsel pidana pokok. Di samping itu bobot pidana yang bisa melebihi pidana pokok denda, yang mana pidana pokok denda hanya bisa di subsiderkan pidana kurungan pengganti, akan tetapi pembayaran uang pengganti dapat disubsiderkan dengan pidana pokok penjara yang lamanya disebutkan dalam putusan hakim sepanjang subsider dari pidana pembayaran uang pengganti tidak melebihi ancaman pidana pokok penjara. Proses penelusuran aset tindak pidana korupsi dilakukan pada tahap penyelidikan dan penyidikan yang kemudian disita yang digunakan dalam proses pembuktian di persidangan, dan sebagai jaminan dalam penjatuhan pidana uang pengganti, yang apabila tidak dibayarkan dalam waktu 1 (satu) bulan aset tersebut dapat dijadikan barang sitaan jaksa dan dilelang untuk menutupi uang pengganti tersebut.

Penerapan pidana uang pengganti terhadap pelaku tindak pidana korupsi kurang maksimal dikarenakan adanya pengaturan yang kurang tegas mengaturnya, dalam perampasan barang sesuai amanat Pasal 18 ayat (1) huruf a KPK memiliki melakukan perampasan barang hasil tindak pidana korupsi, akan tetapi jaksa disini kurang berperan aktif dalam pelaksanaan perampasan barang hasil tindak pidana korupsi.. Pasal 18 ayat (1) huruf a dan b merupakan satu kesatuan yang dimana, apabila terpidana tidak mampu membayar uang pengganti tersebut, berdasarkan Pasal 18 ayat (1) huruf a, bisa dijadikan sebagai barang sitaan dan dilelang oleh jaksa untuk menutupi uang pengganti yang tidak dapat dibayarkan.

\section{DAFTAR PUSTAKA}

\section{Dokumen Hukum}

Kitab Undang-Undang Hukum Pidana

Republik Indonesia, Undang-Undang Tentang Hukum Acara Pidana. UU Nomor 8 Tahun 1981.

21 Lihat Gustav Radbruch dalam Usman, Andi Najemi, Mediasi Penal di Indonesia, Keadilan, Kemanfaatan dan Kepastian Hukum, Undang Jurnal Hukum, Volume 1 No. 1, Tahun 2018, hlm. 79 
Republik Indonesia, Undang-Undang Tentang Perubahan atas Undang-Undang Nomor 31 Tahun 1999 Tentang Pemberantasan Tindak Pidana Korupsi. UU Nomor 20 Tahun 2001. LNRI Tahun 2001 Nomor 134, TLNRI Nomor 4150.

Republik Indonesia, Undang-Undnag Tentang Komisi Pemberantasan Tindak Korupsi. UU Nomor 30 Tahun 2002. LNRI Tahun 2002 Nomor 137. TLNRI Nomor 4250

Republik Indonesia, Undang-Undang Tentang Pengesahan United Nations Convention Against Corruption, 2003 (Konvensi Perserikatan Bangsa-Banga Anti Korupsi, 2003). UU Nomor 7 Tahun 2006. LNRI Tahun 2006 Nomor 32. TLNRI Nomor 4620.

Republik Indonesia, Undang-Undang Tentang Pengadilan Tindak Pidana Korupsi. UU Nomor 46 Tahun 2009. LNRI Tahun 2009 Nomor 155. TLNRI 5074.

Republik Indonesia, Peraturan Mahkamah Agung Tentang Pidana Tambahan Uang Pengganti Dalam Tindak Pidana Korupsi. Perma Nomor 5 Tahun 2014. BNRI Tahun 2014 Nomor 2014. TBNRI Nomor 8.

United Nations Convention on Anti Corruption (UNCAC) tahun 2003.

\section{Buku}

Barda Nawawi Arief. Bunga Rampai Kebijakan Hukum Pidana (Perkembangan Penyusunan Konsep KUHP Baru). Cetakan Keenam. Edisi Kedua. Kencana Prenada Media Grup, Jakarta, 2011.

Chainur Arrasjid. Dasar-Dasar ilmu Hukum. Cetakan Kedua. Sinar Grafika, Jakarta, 2001.

Chaerudin, Syaiful Ahmad Dinar dan Syarif Fadillah. Strategi Pencegahan \& Penegakan Hukum Tindak Pidana Korupsi. Cetakan Kedua. PT Refika Aditama, Bandung, 2009.

Adami Chazawi. Hukum Pidana Korupsi Di Indonesia (Edisi Revisi). Cetakan Pertama. Rajawali Pers, Jakarta, 2016.

Ermansjah Djaja. Memberantas Korupsi Bersama KPK (Komisi Pemberantasan Korupsi). Edisi Kedua. Cetakan Kedua. Sinar Grafika, Jakarta, 2013.

Andi Hamzah. Analisis dan Evaluasi Hukum Tentang Eksaminasi Hakim Mengenai Tindak Pidana Korupsi. Badan Pembinaan Hukum Nasional Dapartemen Hukum Dan Hak Asasi Manusia RI, Jakarta, 2009.

Andi Hamzah. Asas-Asas Hukum Pidana. Cetakan Keempat. PT Rineka Cipta, Jakarta 2010.

Andi Hamzah. Hukum Pidana Indonesia. Cetakan Pertama. Sinar Grafika, Jakarta, 2017.

Evi Hartanti. Tindak Pidana Korupsi (Edisi Kedua). Cetakan Keenam. Sinar Grafika, Jakarta, 2016.

Neni Sri Imaniyati dan Panji Adam. Pengantar Hukum Indonesia Sejarah dan PokokPokok Hukum Indonesia. Cetakan Pertama. Sinar Grafika, Jakarta, 2018. 
Yudi Kristiana. Teknik Penyidikan \& Pemberantasan Tindak Pidana Korupsi. Thafa Media, Yogyakarta, 2018.

Leden Marpaung. Asas - Teori - Praktik Hukum Pidana. Cetakan Ketiga. Sinar Grafika, Jakarta, 2006.

Peter Mahmud Marzuki. Penelitian Hukum. Cetakan Kedua. Kencana Prenada Media Group, Jakarta, 2006.

Bahder Johan Nasution. Metode Penelitian Ilmu Hukum. Cetakan Kedua. Mandar Maju, Bandung, 2016.

Teguh Prasetyo. Hukum Pidana. Cetakan Keenam. PT RajaGrafindo Persada, Jakarta, 2016.

Edi Setiadi dan Kristian. Sistem Peradilan Pidana Terpadu dan Sistem Penegakan Hukum di Indonesia. Prenadamedia Grup, Jakarta, 2006.

Surachmin dan Suhandi Cahaya. Strategi Dan Teknis Korupsi. Sinar Grafika, Jakarta, 2013.

Indah Wahyu Utami dan Widi Nugrahaningsih. Waspada Korupsi Di Sekitar Kita. Istana Media, Yogyakarta, 2015.

Bettina Yahyah. Kedudukan Dan Tanggung Jawab Pidana Korporasi Dalam Tindak Pidana Korupsi. Publitbang Hukum dan Peradilan Badan Litbang Diklat Kumdil Mahkamah Agung RI, Jakarta, 2016.

Bettina Yahyah. Budi Suhariyanto dan Muh. Ridha Hakim. Urgensi dan Mekanisme Pengembalian Aset Hasil tindak Pidana Narkotika. Publitbang Hukum dan Peradilan Mahkamah Agung Republik Indonesia, Jakarta, 2017.

\section{Jurnal/Majalah Ilmiah}

Nys. Arfa. Analisis Yuridis Penjatuhan Pidana Tambahan Uang Pengganti dalam UndangUndang Nomor 31 Tahun 1999 Jo undang-Undang Nomor 20 Tahun 2001 Tentang Pemberantasan Tindak Pidana Korupsi. Jurnal Ilmu Hukum, Vol. 8, No. 1, Fakutas Hukum Universitas Jambi, Jambi, 2017.

Basir Rohrohmana. Pidana Pembayaran Uang Pengganti Sebagai Pidana Tambahan Dalam Tindak Pidana Korupsi. Jurnal Hukum Prioris Vol. 6, No.1, Fakultas Hukum Universitas Cenderawasih, Jayapura, 2017.

Ridwan Arifin et.al., "A Comparative Analysis of Indonesia's KPK and Hong Kong ICAC in Eradicating Corruption," Jambe Law Journal, Vol. 2, No.2, 2019.

Mohamad Rapik et.al., "Peran Forum Koordinasi Pencegahan Terorisme dalam Menjalankan Program Deradikalisasi," Journal of Political Issues, Vol. 1, No. 2, 2020.

Lukas, Ade Paul. Efektivitas Pidana Pembayaran Uang Pengganti Dalam Tindak Pidana Korupsi. Jurnal Dinamika Hukum Vol. 10, No. 2, Jawa Barat, 2010. 
Usman, Andi Najemi, Mediasi Penal di Indonesia, Keadilan, Kemanfaatan dan Kepastian Hukum, Undang Jurnal Hukum, Vol. 1, No. 1, Tahun 2018.

\section{Website}

http://huda-drchairulhudashmh.blogspot.com/2015/06/menyoal-pidana-tambahanpembayaran-uang.html.

https://www.kpk.go.id/id/tentang-kpk/fungsi-dan-tugas.

https://www.cifor.org/ilea/ref/ina/instruments/Law Enforcement/AssetRecovery/i ndex.htm.

https://www.kpk.go.id/id/berita/siaran-pers/717-capaian-dan-kinerja-kpk-di-tahun2018. 